\title{
Bionomics of Freyeria trochylus (Freyer, 1844) and Zizeeria karsandra (Moore, 1865) (Lepidoptera, Lycaenidae) on Rodos Island, Greece
}

\author{
Christos J. Galanos ${ }^{1}$ \\ 1 Independent Researcher of the flora and the butterfly fauna of the Dodecanese Island Complex, Parodos Filerimou, \\ 85101 Ialisos, Rodos, Greece; galanosx@gmail.com
}

http://zoobank.org/DB32F726-CF0A-4C49-BBD7-831C4251C4E0

Received 16 November 2019; accepted 20 February 2020; published: 15 April 2020

Subject Editor: Zdenek Fric.

\begin{abstract}
This study is focused on the presence of Freyeria trochylus (Freyer, 1844) and Zizeeria karsandra (Moore, 1865) on Rodos Island, Greece. F. trochylus was first found there by Turati and Fiori in 1923 and Z. karsandra by Bender in 1958. The distributional range of both species in Europe including the Mediterranean and their habitat and ecology, including their associations with ants, together with their life history and larval hostplants are examined. The life cycle of Z. karsandra is described and illustrated here for the first time for Europe as a whole.
\end{abstract}

\section{Introduction}

During recent surveys and studies of the butterfly fauna in the Dodecanese Islands conducted by the author (Galanos 2014, 2016, 2017), the distribution of two lycaenids, Freyeria trochylus (Freyer, 1844) and Zizeeria karsandra (Moore, 1865), has remained unclear since their first historical records on the island of Rodos (see below).

Freyeria trochylus has been considered as one of the scarcest butterflies in Europe, although it is classified as of Least Concern (LC), according its status in the most recent IUCN Red List (Van Swaay et al. 2010). The species has a vast distribution in the Old World, from SE Europe, Africa and Madagascar to Asia through Himalayas (de Freina 2014). In Europe, it is recorded from Turkey, Greece, Cyprus and Bulgaria (Makris 2003; Pamperis 2009; Langourov et al. 2013). In Greece, the focus of this paper, it has been reported in the provinces of Macedonia, Thessalia, Evvia, Hios, Peloponnisos, Samos, Thasos, Crete, Kasos and Rodos, whereas in Bulgaria it is currently known to exist only in a single location near the Bulgarian-Greek border (Ignatov et al. 2013), a record which, however, is dubious (Langourov 2019, pers. comm.).

In Rodos, a single male specimen of F. trochylus was collected and recorded for the first time in August 1923 by Turati and Fiori (Olivier 1993). That was the third oldest record in Greece and Europe as a whole, following one in Crete in 1841 and another in Sterea Hellas (Evrytania and Parnassos) in 1861 (Frivaldszky 1845; de La Chavignerie 1861). The most recent reports for Rodos were by Klimesch in 1971 and 1983 (Olivier 1993).

Similarly, the known distribution of Z. karsandra in Europe including the Mediterranean ranges from Algeria and Sicily to the east, through Tunisia, Libya, Egypt, Israel, Lebanon, Greece, Cyprus and Turkey (Hesselbarth et al. 1995; Makris 2003; Baytaş 2007; Benyamini 2009; Pamperis 2009; Viborg 2019). In Greece, its presence has been reported so far only on Rodos and Crete (Bender 

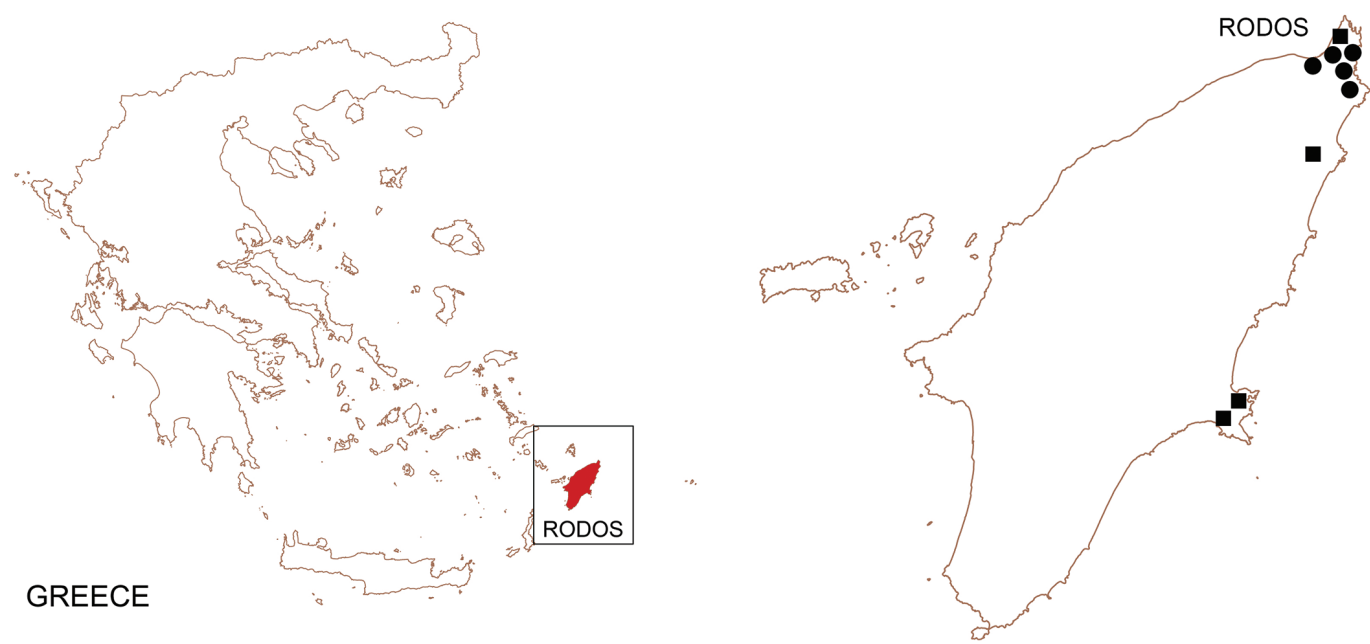

Figure 1. Geographical position of the Island of Rodos in Greece. Distribution of Freyeria trochylus ( $\square$ ) and Zizeeria karsandra $(\bullet)$ in the studied area.

1963; Olivier 1993; Pamperis 2009; Rowlings and Cuvelier 2018; Viborg 2019). On Rodos, it was reported for the first time as a new species of the butterfly fauna of the island by Bender in 1963. Based on the results of his survey on the island in May 1958, the specimen was recorded identified as Zizeeria lysimon (Hübner, 1803), which is a synonym for Zizeeria knysna (Trimen, 1862), the distribution of which, however, ranges from Algeria to the west and southern Africa to Madagascar (Bender 1963; Larsen 1986; Olivier 1993; Williams 2008).

It should be noted, however, that Bender's report does not provide any data concerning dates, localities, collected specimens or photographs. To address this deficiency, the current study contributes detailed bionomic information for both species, including photographs, videos available in online Suppl. materials $1-3$, in addition to notes on hostplants, larval relationships with ants and general life cycle.

\section{Material and methods}

Photographs of live material of both species were taken in situ during field work and ovipositions on the larval hostplant of each species were captured on videos. Early stages of Zizeeria karsandra were measured by taking the length across the body of larvae, as well as the length and width (at its broadest point) of the pupa, using a digital calliper (TOTAL TMT321501). In making measurements between instars we referred to the works of Sakauchi et al. (2019) and Venkata Ramana et al. (2014). We were able to track the different larval stages by measuring larval frass particles in accordance with Bean (1959) and Southwood and Henderson (2000). No specimen collection was carried out due to conservation considerations and was not necessary since the species could not be confused with other lycaenids and detailed photos were taken. Taxonomy and nomenclature follow Wiemers et al. (2018) for the butterfly fauna, Hassler et al. (2019) and Kleinsteuber et al. (2016) for the flora. All photographs and videos by Christos Galanos. 


\section{Results and discussion}

\section{Freyeria trochylus}

Freyeria trochylus is Europe's smallest butterfly. Its small size with a wingspan of 15-18 mm and its rapid flight when close to the ground are probably the main reasons why it has often been overlooked. It is a highly adaptable species to varying environmental conditions, especially to climatic and edaphic ones (de Freina 2014). The species is protected by Greek Law (Presidential Decree 67/81).

In order to verify the presence of $F$. trochylus on Rodos, systematic field work was conducted by the author from August to November 2019 in four study areas (Fig. 1), from the northern part of the island southwards to Lindos. These are characterized by dry and stony ground exposed to high temperatures, where the occurrence of its likely hostplant, Andrachne telephioides L. (Fig. 2B, C, Suppl. material 4: Figure S6) had been documented.

From the $13^{\text {th }}$ of August to the $19^{\text {th }}$ of November 2019, 31 adults in total, males and females, were recorded (Fig. 2A, Suppl. material 4: Figure S5) and more than 50 plants with feeding marks were examined in detail, on which 26 caterpillars feeding or resting on leaves or shoots were found. In addition, more than 30 eggs (Fig. 2D), hatched and un-hatched, were counted and 8 ovipositions took place. All the female individuals were observed to lay eggs individually, exclusively on the leaves, stems and perianth of $A$. telephioides plants (Suppl. material 1: Video S1), which is for the first time confirmed as the larval hostplant of F. trochylus on Rodos, instead of Heliotropium hirsutissimum Grauer, as Olivier hypothesised (Olivier 1993).

As it turned out in the field, larvae of $F$. trochylus have relationships with ant species, as many lycaenid larvae do to protect themselves from natural enemies like flies or wasps (Fiedler 2006; Obregón et al. 2015). Actually, most of them were found to maintain a mutually beneficial relationship with worker ants of the Formicidae family (Fig. 2E, F), probably Camponotus piceus Leach, 1825, which is widespread and common in Mediterranean countries including Greece (Fiedler 2019, pers. comm.) and is regarded as one of the most important ant associates of Palaearctic lycaenids (Fiedler 2006). The ants were observed feeding on larval secretions of the third and fourth instar, which are known to secrete nutritious liquids consisting of sugars and amino acids from their honey glands (Tolman 1995; Fiedler 2006).

As further investigations are still in progress regarding the life cycle of $F$. trochylus on Rodos, the only known related report for Greece to date is by Tolman, according to which the ovum stage lasts for about 1 week, while the pupal stage lasts about 2 weeks (Tolman 1995). On Rodos, this species is estimated to be on the wing throughout most months of the year spanning three generations, with the last record made on the $19^{\text {th }}$ of November 2019.

\section{Zizeeria karsandra}

Zizeeria karsandra is also a tiny butterfly with a wingspan of 15-20 mm, which flies quite rapidly near the ground and thus is easily overlooked. During a series of field surveys since early November 2019 its presence was documented at 5 localities from the northern part of the island westwards to Theologos and southwards to Lindos (Fig. 1).

The habitat where the butterflies were observed was typical of the species, namely open grassy places, roadside verges, moist and waste places near urban areas or next to the sea (Fig. 3C, Suppl. material 4: Figures S11-S15). The study areas were chosen on the basis of the occurrence of the 


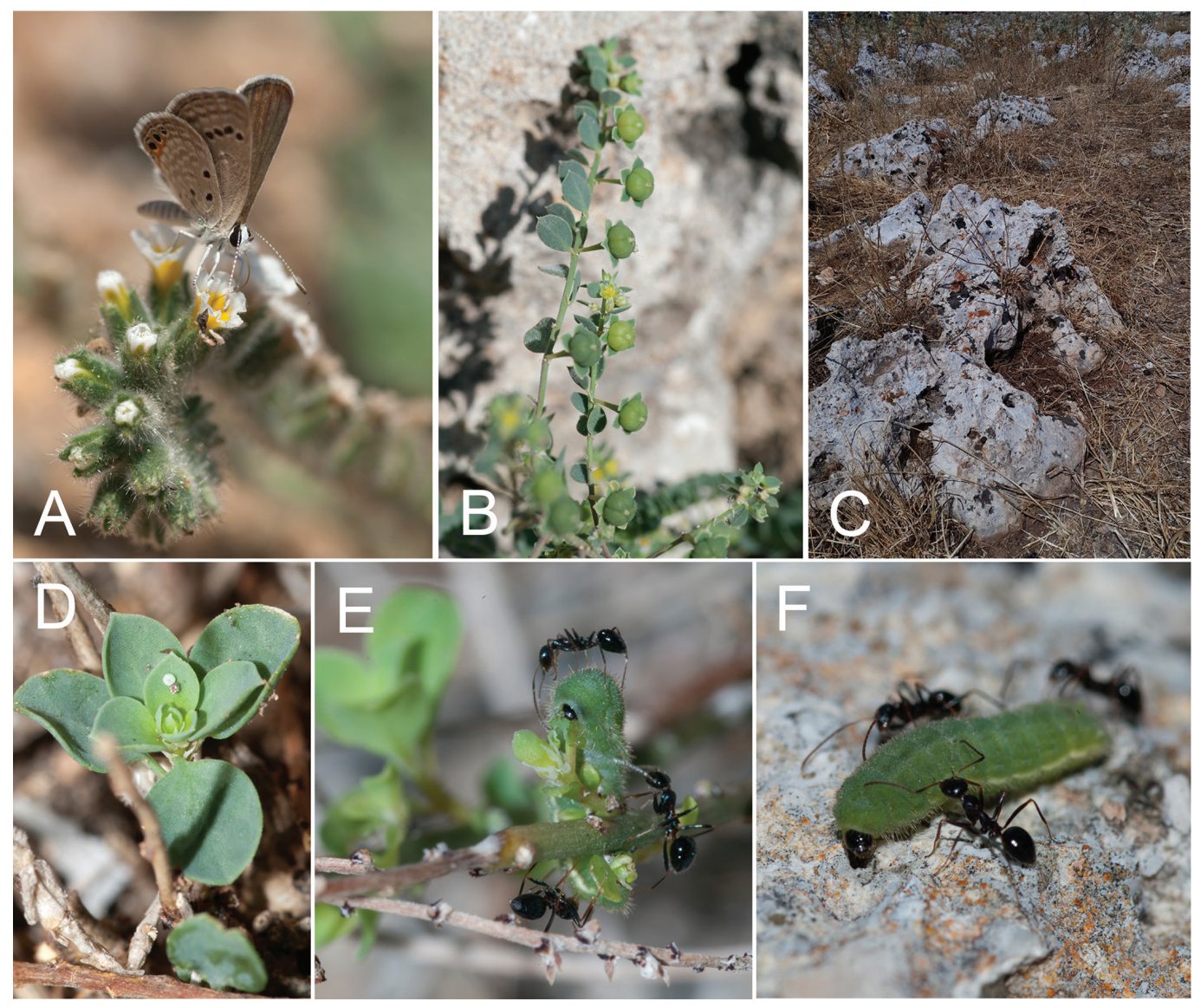

Figure 2. A: Female of Freyeria trochylus feeding on Heliotropium hirsutissimum, Rodos, 13 Aug 2019; B: Andrachne telephioides, the larval hostplant of F. trochylus in Rodos, Rodos, 24 Sep 2019; C: Natural habitat occupied by F. trochylus butterflies, Lindos, 21 Aug 2019; D: Egg of F. trochylus on a fresh leaf of A.telephioides, Pefki, 27 Oct 2019; E, F: Larvae of F. trochylus in association with ant species, Rodos, 22 Oct 2019.

assumed butterfly's hostplant, Polygonum equisetiforme Sm. (Fig. 3 B) (Benyamini 2004). The composition of plant communities did not differ among study areas. In particular, the following plants were found to be abundant: Amaranthus blitoides S. Watson, A. viridis L., Arundo donax L., Capparis orientalis Veill., Cichorium intybus ssp. glabratum (C. Presl) Wagenitz \& Bedarff, Cynodon dactylon (L.) Pers., Dittrichia viscosa ssp. angustifolia (Béguinot) Greuter, Ecballium elaterium (L.) A. Richard, Heliotropium dolosum De Notaris, H. hirsutissimum Grauer, Malva multiflora (Cav.) Soldano et al., Ononis spinosa L., Oxalis pes-caprae L., Polygonum equisetiforme, Portulaca oleracea L., Ricinus communis L., Theligonum cynocrambe L., Thymelaea hirsuta (L.) Endl. and Tribulus terrestris L.

Field work was carried out on sunny mornings with temperatures ranging from $20{ }^{\circ} \mathrm{C}$ to $24{ }^{\circ} \mathrm{C}$, during which time, 13 adults, of which six males and seven females were found to be very active flying or resting close to the ground (Fig. 3 A, Suppl. material 4: Figures S7-S9, Suppl. material 3: 


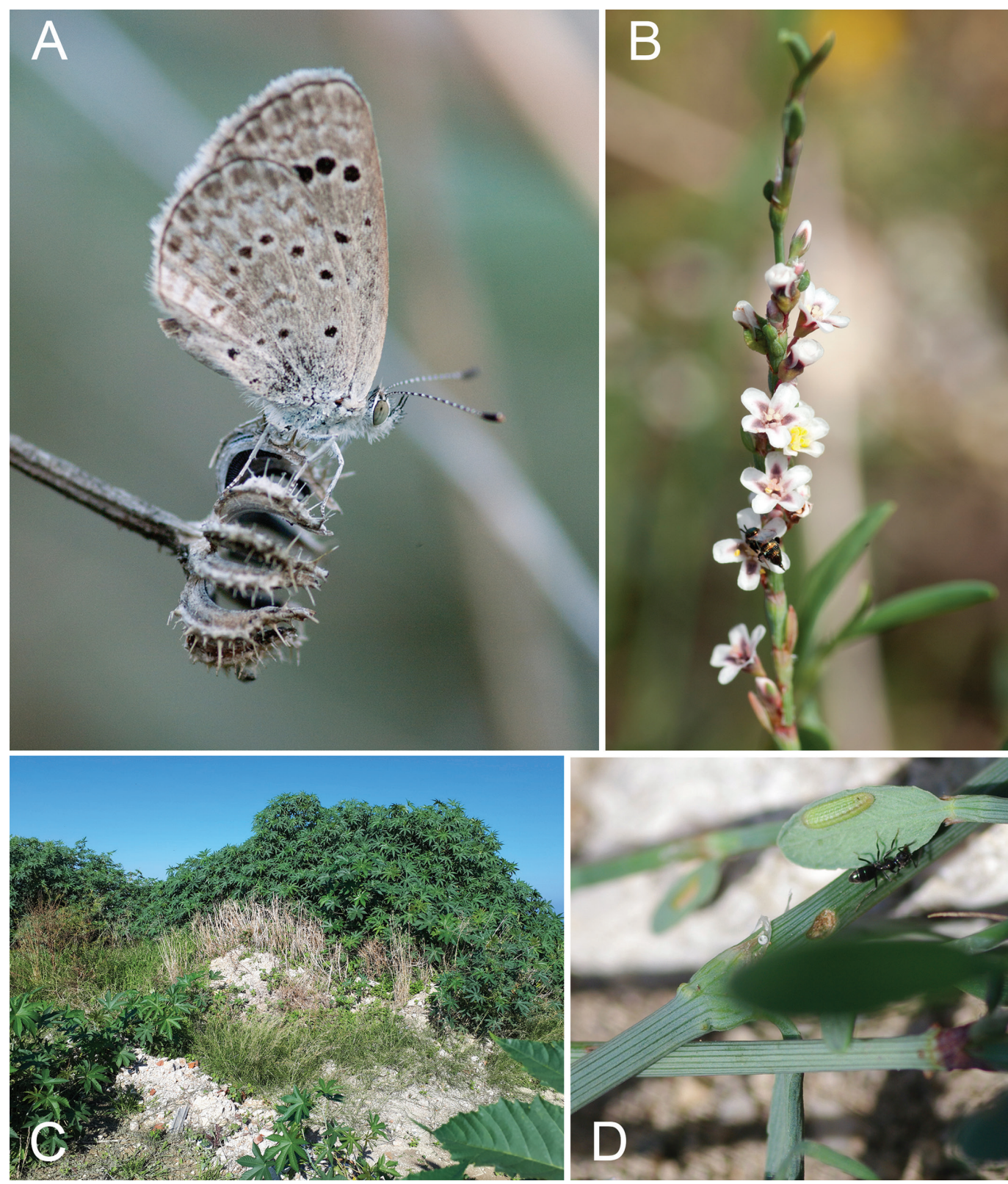

Figure 3. A: Male of Zizeeria karsandra, Rodos, 8 Nov 2019; B: P. equisetiforme, the larval hostplant of Z. karsandra in Rodos, Rodos, 1 Oct 2015; C: Natural habitat occupied by Zizeeria karsandra butterflies, Rodos, 9 Nov 2019; D: Z. karsandra caterpillar feeding on leaves of P. equisetiforme, next to its eggshell, attended by a Tapinoma sp. worker ant near its nest, Rodos, 12 Nov 2019.

Video S3), while three ovipositions took place on fresh stems of $P$. equisetiforme plants on the $8^{\text {th }}$, $12^{\text {th }}$ and $20^{\text {th }}$ of November (Fig. 4A). The butterflies were observed to walk on the shoots, stopping intermittently to lay eggs, always individually (Suppl. material 2: Video S2). 
Additionally, a single larva of the second instar of this species with a length of $4 \mathrm{~mm}$ was found on the $12^{\text {th }}$ of November to be attended by ants next to their nest (Fig. 3D). The ants were identified as worker ants of the genus Tapinoma Foerster, 1850, of the Formicidae family, which have been recorded as regular visitors for quite a number of lycaenid species in the Mediterranean (Fiedler 2019, pers. comm.).

Following a similar pattern, larvae of Z. karsandra in India are attended by ants of the same genus, Tapinoma melanocephalum Fabricius, 1793 (Venkata Ramana et al. 2014), while in Spain (Cordoba) it has been documented that larvae of $Z$. knysna are attended by more than one ant species, in particular, by Formica cunicularia Latreille, 1798, Lasius niger Linnaeus, 1758 and Pheidole pallidula Nylander, 1849 (Obregón et al. 2015).

Concerning its flight period, Z. karsandra is estimated to be on the wing throughout most months of the year spanning three generations, the first of which in early spring and the last in October-November, as it has been similarly reported on Crete (Pamperis 2009; Rowlings and Cuvelier 2018; Viborg 2019). A worn male of this species was found to fly on the $3^{\text {rd }}$ of December, this being the latest report of the year in Greece.

In southern Turkey, Z. karsandra was recorded to be on the wing from the $5^{\text {th }}$ of January to the $20^{\text {th }}$ of December, having taken into account 164 records of adult butterflies (www.adamerkelebek.org).

\section{Life cycle}

In order to accurately study the life cycle of Z. karsandra and its metamorphosis on its hostplant, P. equisetiforme, during the period of the butterfly's early life stages including egg, larva and pupa, the following experiment was conducted in situ by the author.

The shoots of the mature plants of $P$. equisetiforme, where the larva that was found on the $12^{\text {th }}$ of November 2019 and also where the female deposited its eggs on the $20^{\text {th }}$ of November 2019 (11:40 a.m.), were placed into transparent mesh bags and remained in situ, and meticulously closed preventing prospective predators from entering and simultaneously allowing both light and air to pass through. The larva in the first bag was found dead from parasitism on the $28^{\text {th }}$ of November 2019; it was fully grown one or two days prior to pupation. The second bag was examined in situ three times a day during the ovum stage and was transferred to the laboratory after hatching with an average air temperature of $20{ }^{\circ} \mathrm{C}$ and humidity of $75 \%$. Fresh shoots of $P$. equisetiforme with flowers and leaves were supplied each day in the morning, while the bag was cleaned once a day. Larvae were alternatively supplied with leaves of Oxalis pes-caprae L., which has been described as the hostplant of Z. karsandra in Crete; however, they refused to feed on them.

Egg: The egg deposited on the $20^{\text {th }}$ of November hatched after 9 days of incubation, specifically, in the early morning of the $29^{\text {th }}$ of November (Fig. 4A, B). It was white-greenish to bluish in colour when laid and turned into creamy grey on the last day before hatching. It measured $0.5 \mathrm{~mm}$ in diameter and $0.30 \mathrm{~mm}$ in height with a flattened profile and round shape.

Larva: The larvae passed through four instars and moulted thrice as confirmed from observations of their exuviae.

$1^{\text {st }}$ Instar: On the first day of hatching, the young larva measured $1.10 \mathrm{~mm}$ in length (Fig. 4C). Its body was cream to yellowish with long lateral hairs and its head was shiny black as it was in all instars. It was observed to consume only the soft parts of the perianth, avoiding leaves. This stage lasted for a week and the larva grew up to $2.1 \mathrm{~mm}$. 


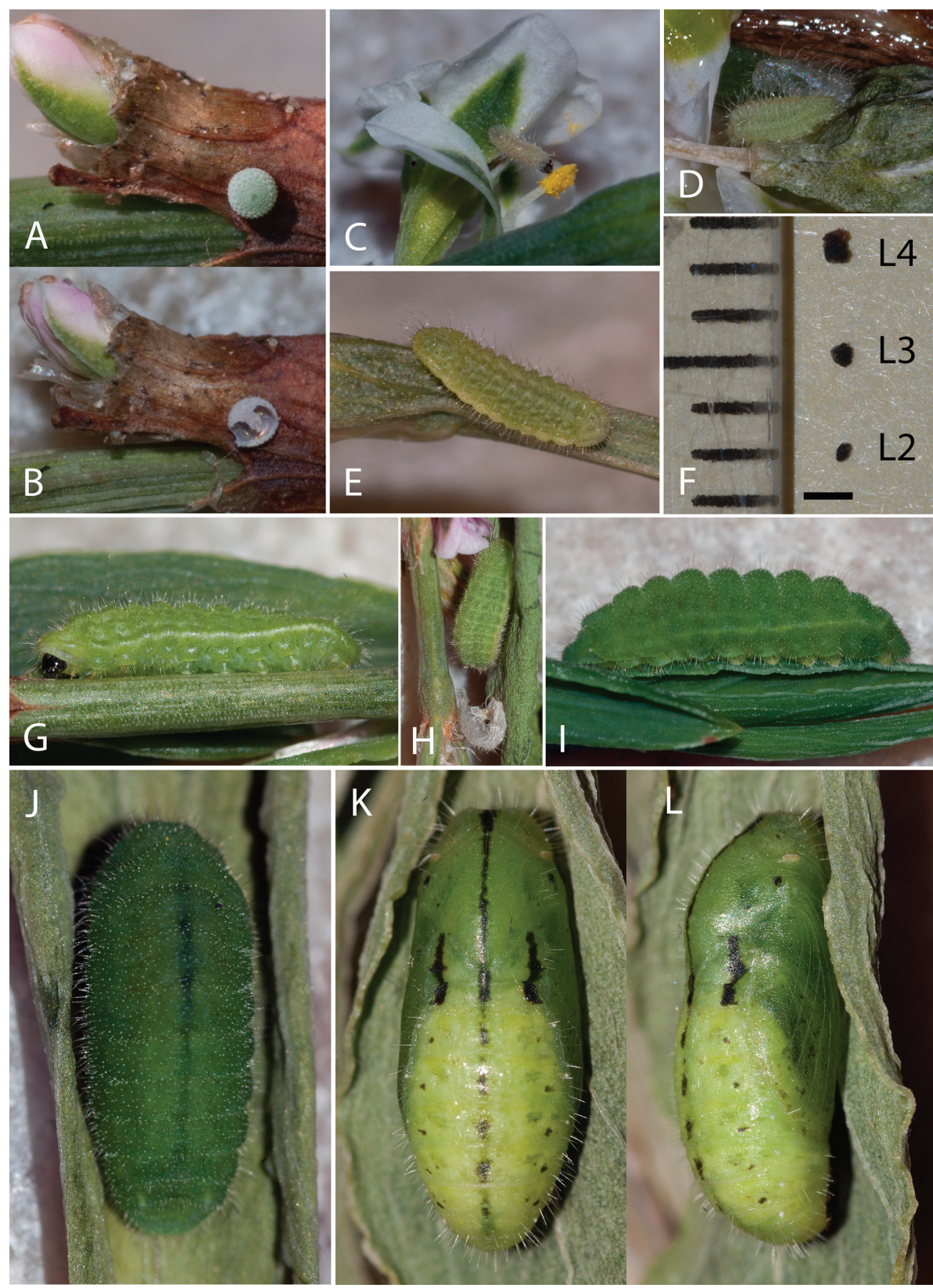

Figure 4. The metamorphosis of Z. karsandra during the early stages of its life cycle. A, B: Egg of Z. karsandra before and after hatching on a fresh leaves of its hostplant, P. equisetiforme; C: The new hatched larva of the $1^{\text {st }}$ instar; D: The larva during the process of the first ecdysis into the $2^{\text {nd }}$ instar; $\mathbf{E}$ : The $2^{\text {nd }}$ instar larva moving on its hostplant; F: A comparison of the collected frass pellets of the fully grown larvae of the $2^{\text {nd }}(\mathrm{L} 2)$, $3^{\text {rd }}(\mathrm{L} 3)$ and $4^{\text {th }}$ (L4) instars. Scale bar: $1 \mathrm{~mm}$; G: The $3^{\text {rd }}$ instar larva, lateral view; H: The new moulted larva next to its exuvia after the process of the last ecdysis from the $3^{\text {rd }}$ into the final and the $4^{\text {th }}$ instar; I: The fully grown $4^{\text {th }}$ instar larva, lateral view; J: the $4^{\text {th }}$ instar larva at the pre-pupal stage, dorsal view; K, L: The new formed pupa, dorsal and lateral view, Rodos, 8 Nov 2019. All photographs by Christos Galanos. 
$2^{\text {nd }}$ Instar: An ecdysis was detected and photographed on the $7^{\text {th }}$ of December, 8 days after hatching, marking the transition from the first to the second larval instar (Fig. 4D, E). During the process of the moulting the larva's head became green in colour, while reverting to black after it was completed. At this stage, the larva's body became greener and the frass pellets measured were clearly bigger than during the previous instar. The larva was observed feeding on leaves for the first time. This stage lasted for seven days and the larva grew up to $4 \mathrm{~mm}$.

$3^{\text {rd }}$ Instar: On the $14^{\text {th }}$ of December a second ecdysis took place marking the transition from the second to the third instar. At the same time, frass pellets became clearly bigger than in the previous instar and the larva grew up to $6.4 \mathrm{~mm}$ (Fig. 4G). This stage lasted for seven days.

$4^{\text {th }}$ Instar: On the $21^{\text {st }}$ of December the last ecdysis was detected from the third to the fourth and final instar (Fig. 4H, I). At this stage frass pellets were found distinctly bigger than in the previous instar, while the larva grew up to $10.3 \mathrm{~mm}$. This stage lasted for seven days.

In all cases concerning the process prior to ecdysis, the larvae were observed to be entirely still for approximately 36 hours. Frass were collected and measured comparatively. The comparison found each instar to be noticeably distinct from the others (Fig. 4F). It should be noted that the frass pellets were collected from a limited area where the larvae fed exclusively on the particular hostplant, $P$. equisetiforme, both localised frass and larval specialisation being regarded as significant parameters in such an experiment (Southwood and Henderson 2000).

Pupa: At the pre-pupal stage the fully grown fourth-instar larva became inactive, stopped feeding and the last frass pellets were excreted. Subsequently, the larva became shorter and thicker before pupation (Fig. 4J). This stage lasted for three days $\left(28^{\text {th }}-30^{\text {th }}\right.$ of December). The pupa was newly formed on $31^{\text {st }}$ of December and it measured $8.2 \mathrm{~mm}$ in length and $3.7 \mathrm{~mm}$ in width at its broadest point (Fig. 4K, L). It was a translucent pale yellowish-green when first formed, while as the adult butterfly developed it eventually darkened and the wings and other parts of its body became visible through the pupal case. As it turned out, it was not attached to its cell by any girdle or the cremaster, however, the old larval skin remained attached to the end of the pupa for a few hours (Suppl. material 4: Figure S10). The pupa was transported back to its natural habitat with an average air temperature of $12{ }^{\circ} \mathrm{C}$ and humidity of $80 \%$, where it was found having hatched on the $19^{\text {th }}$ of January 2020. This stage lasted for 20 days. Thus Z. karsandra completes its life cycle in 61 days (Egg: 9 days in situ, larva: 32 days to the laboratory, pupa: 20 days in situ).

In conclusion, $P$. equisetiforme is verified as the principal larval hostplant of $Z$. karsandra on the island of Rodos and the early parts of its life cycle are also documented for the first time for Greece and for Europe as a whole in the present study, which, in particular, is focused on details of egg-laying habits, larval hostplant and habitat preferences, as well as on larval and adult behaviour. Furthermore, it contributes to knowledge on the identification of each larval instar of this species, the morphological traits and periods of each life stage and the development from egg to adult under climatic and environmental conditions in Greece. It should be noted that detailed research on the biology of Z. karsandra has been carried out only in India (Venkata Ramana et al. 2014; Harinath et al. 2015). Regarding the conservation status of Z. karsandra in Greece, the species has been classified as Vulnerable due to overcollecting and the destruction of its habitat (Pamperis 2009), and thus it is protected by Greek Law (Presidential Decree 67/81). Its status in Rodos cannot be currently assessed because there have only been very few records; however, the most important threat can be assumed to be habitat change and loss due to residential development and road construction. 


\section{Acknowledgements}

All research was conducted with the permission of the Greek Ministry of Environment, Energy and Cli-

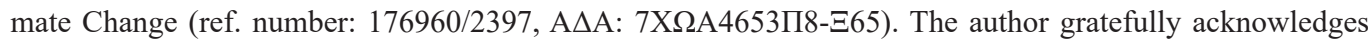
the General Directorate for the Protection and Development of Forests and the Rural Environment of the Greek Ministry of Environment and Energy for the permission to carry out surveys of both flora and fauna, especially in areas protected by the European Network "Natura 2000", on the islands of the Dodecanese Complex. Special thanks go to Prof. Dr. Konrad Fiedler for his kind assistance in ant species identification, Dr. Mario Langourov for sharing information on the distribution of F. trochylus in Bulgaria, as well as to Dr. Zdenek Fric, Dr. David Lees and the two reviewers for their suggestions and valuable comments on earlier drafts of this manuscript.

\section{References}

AdaMerOs-Butterflies of Turkey (2019) AdaMerOs-Butterflies of Turkey. http://www.adamerkelebek.org/ IcerikDetay.asp?IcerikKatId=7\&TurId=11 [accessed 10 Nov 2019]

Baytaş A (2007) A Field Guide to the Butterflies of Turkey. İstanbul: NTV Yayınları.

Bean JL (1959) Frass size as an indicator of spruce budworm larval instars. Annals of the Entomological Society of America 52: 605-608. https://doi.org/10.1093/aesa/52.5.605

Bender R (1963) Beiträgezur Lepidopterenfauna der Insel Rhodos. Zeitschrift der Wiener Entomologischen Gesellschaft 48: 11-20. [pls. 6, 7]

Benyamini D (2004) Lythrum salicaria (Lythraceae) - a confirmed summer hostplant of Leptotes pirithous in Israel (Lycaenidae: Polyommatinae). Nota Lepidopterologica 26 (3/4): 99-101.

Benyamini D (2009) Butterfly Gardening in Israel and the Middle East. Keter Publishing, Jerusalem, 357 pp. de Freina JJ (2014) A zoogeographic, ecological and taxonomic study of the sibling species Chilades trochylus Freyer, 1845 and Chilades putli Kollar, 1848 (Lepidoptera: Lycaenidae, Lycaeninae, Polyommatini). Nachrichten des Entomologischen Vereins Apollo, N.F. 34(4): 145-160.

de La Chavignerie B (1861) Note relative á des Lépidoptères recueillis en Grèce (Eurytanie et Monts Parnasse). Annales de la Société entomologique de France, Paris. 40(1).

Fiedler K (2006) Ant-associates of Palaearctic lycaenid butterfly larvae (Hymenoptera: Formicidae; Lepidoptera: Lycaenidae) - a review. Myrmecologische Nachrichten 9: 77-87.

Frivaldszky I (1845) Rövid áttekintése egy természetrajzi utazásnak, azeurópai Törökbirodalomban, egyszersmind nehány a közben újdonnat fölfedezett állatnak leírása. [Brief overview of a natural history journey taken in the European part of the Ottoman Empire, supplemented with the description of some newly discovered animals]. A Kiralyi Magyar természettudományi társulat evkonyvei (1841-1845):163-187.

Galanos CJ (2014) First records of Pararge aegeria and Cacyreus marshalli, and a verification of Muschampia proto from the Greek Island of Rhodes. First records of Cacyreus marshalli and Gegenes sp. from the Greek Island of Tilos; Dodecanese Complex S.E. Aegean (Lepidoptera: Hesperioidea \& Papilionoidea). Phegea 42(4): 74-77.

Galanos CJ (2016) Butterflies and Skippers of the South East Aegean Island of Hálki, Dhodhekánisa (= Dodecanese) Island Complex, Greece, representing 16 first records for the island. First record of Cacyreus marshalli from the Greek Island of Sími. An update of the Butterfly and Skipper Fauna of the Greek Island of Rhodos (Lepidoptera: Papilionoidea \& Hesperioidea). Phegea 44(3): 80-87.

Galanos CJ (2017) First record of Danaus chrysippus from the Island of Simi (Symi), SE Aegean, Greece (Lepidoptera: Nymphalidae, Danainae). Phegea 45(4): 105-106. 
Harinath P, Suryanarayana K, Venkata Ramana SP (2015) Eco-biology of the dark grass blue butterfly, Zizeeria karsandra (Moore) (Lepidoptera: Rhopalocera: Lycaenidae) from the Eastern Ghats of Southern Andhra Pradesh. Journal of Entomology and Zoology Studies 3(5): 225-231.

Hassler M, Schmitt B, Kleinsteuber A (2014) Flora of Rhodes. http://worldplants.webarchiv.kit.edu/rhodos/ [accessed 8 November 2019]

Hesselbarth G, van Oorschot H, Wagener S (1995) Die Tagfalter der Türkeiunter Berücksichtigung der angrenzenden Länder. 3 band. Selbstverlag Sigbert Wagener Hemdener Weg 19, D 46399, Bocholt, Germany.

Ignatov A, Wetton P, Beshkov S (2013) Chilades trochylus (Freyer, [1845]) (Lep.: Lycaenidae) confirmed for the Bulgaria fauna and doubt cast on earlier records of this and other species. Entomologist's Record and Journal of Variation, 125: 119-122.

Kleinsteuber A, Ristow M, Hassler M (Eds) (2016) Flora von Rhodos und Chalki. Band 1: Allgemeiner Teil. Spezieller Teil: Polypodiopsida, Equisetopsida und Lycopodiopsida. Pinopsida und Gnetopsida. Magnoliopsida (Familien A-F). Naturwissenschaftlicher Verlag A. Kleinsteuber, Karlsruhe.

Langourov M, Simov N, Abadjiev S (2013) Chilades trochylus (Freyer, [1845]) (Lep.: Lycaenidae), new for the North Aegean islands. Entomologist's Record and Journal of Variation, 125(137): 1-143.

Larsen TB (1986) Tropical butterflies of the Mediterranean. Nota Lepidopterologica 9(1-2): 63-77.

Makris C (2003) Butterflies of Cyprus. The Bank of Cyprus Cultural Foundation, Nicosia.

Obregón R, Shaw MR, Fernández-Haeger J, Jordano D (2015) Parasitoid and ant interactions of some Iberian butterflies (Insecta: Lepidoptera). SHILAP Revista de Lepidopterología 43(171): 439-454.

Olivier A (1993) The Butterflies of the Greek Island of Ródos: Taxonomy, Faunistics, Ecology and Phenology with a Tentative Synthesis on the Biogeography of the Butterflies of Kriti (Crete), Karpathos, Ródos, the Eastem Aegean islands and Kipros (Cyprus) (Lepidoptera: Hesperioidea \& Papilionoidea). Vlaamse Vereniging Voor Entomologie, Antwerpen, $250 \mathrm{pp}$.

Pamperis LN (2009) The butterflies of Greece. Second Edition revised and enlarged. Editions Pamperis, Athens, $766 \mathrm{pp}$.

Rowlings M, Cuvelier S (2018) Zizeeria karsandra (Lepidoptera: Lycaenidae) recorded from Crete (Greece): observations, distribution and habitats. Phegea 46: 126-131.

Sakauchi K, Taira W, Toki M, Iraha Y, Otaki JM (2019) Overwintering States of the Pale Grass Blue Butterfly Zizeeria maha (Lepidoptera: Lycaenidae) at the time of the Fukushima nuclear accident in March 2011. Insects 10: 1-389. https://doi.org/10.3390/insects10110389

Southwood TRE, Henderson PA (2000) Ecological Methods. Third Edition, Blackwell Science, USA, 575 pp.

Tolman T (1995) Notes on the life-cycle of Chilades trochylus (Freyer, 1844) in Greece and a new hostplant family for European butterflies (Lepidoptera: Lycaenidae). Linneana Belgica, Pars XV, No 1.

Van Swaay C, Cuttelod A, Collins S, Maes D, López Munguira M, Šašić M, Settele J, Verovnik R, Verstrael T, Warren M, Wiemers M, Wynhof I (2010) European Red List of Butterfies. Luxembourg: Publications Office of the European Union.

Venkata Ramana SP, Harinath P, Prasanna Kumar V (2014) Life history of the dark grass blue Zizeeria karsandra (Lepidoptera: Rhopalocera: Lycaenidae) From Southern Andhra Pradesh-India. Centre for Info Bio Technology (CIBTech) Journal of Zoology 3(1): 1-6.

Viborg AL (2019) Supplementary information on Zizeeria karsandra (Lepidoptera: Lycaenidae) on Crete. Phegea 47(3): 93-96.

Wiemers M, Balletto E, Dincă V, Fric ZF, Lamas G, Lukhtanov V, Munguira ML, van Swaay CAM, Vila R, Vliegenthart A, Wahlberg N, Verovnik R (2018) An updated checklist of the European Butterflies (Lepidoptera, Papilionoidea). ZooKeys 81: 9-45. https://doi.org/10.3897/zookeys.811.28712

Williams MC (2008) Butterflies and Skippers of the Afrotropical Region (Papilionoidea and Hesperioidea). An Encyclopaedia, $7^{\text {th }}$ edition, Pretoria. 


\section{Supplementary material 1}

\section{Video S1}

Authors: Christos J. Galanos

Data type: multimedia

Explanation note: Female of Freyeria trochylus, ovipositing on the leaves of its larval hostplant, Andrachne telephioides. Rodos, 21 Aug 2019.

Copyright notice: This dataset is made available under the Open Database License (http://opendatacommons.org/licenses/odbl/1.0/). The Open Database License (ODbL) is a license agreement intended to allow users to freely share, modify, and use this Dataset while maintaining this same freedom for others, provided that the original source and author(s) are credited.

Link: https://doi.org/10.3897/nl.43.48535.suppl1

\section{Supplementary material 2}

\section{Video S2}

Authors: Christos J. Galanos

Data type: multimedia

Explanation note: Female of Zizeeria karsandra, ovipositing on the shoot of its larval hostplant, Polygonum equisetiforme. Rodos, 8 Nov 2019.

Copyright notice: This dataset is made available under the Open Database License (http://opendatacommons.org/licenses/odbl/1.0/). The Open Database License (ODbL) is a license agreement intended to allow users to freely share, modify, and use this Dataset while maintaining this same freedom for others, provided that the original source and author(s) are credited.

Link: https://doi.org/10.3897/nl.43.48535.suppl2

\section{Supplementary material 3}

\section{Video S3}

Authors: Christos J. Galanos

Data type: multimedia

Explanation note: A male individual of Zizeeria karsandra resting on a leaf of Ononis spinosa. Rodos, 8 Nov 2019. All videos by Christos Galanos.

Copyright notice: This dataset is made available under the Open Database License (http://opendatacommons.org/licenses/odbl/1.0/). The Open Database License (ODbL) is a license agreement intended to allow users to freely share, modify, and use this Dataset while maintaining this same freedom for others, provided that the original source and author(s) are credited.

Link: https://doi.org/10.3897/nl.43.48535.suppl3 


\section{Supplementary material 4}

\section{Figures S5-S15}

Authors: Christos J. Galanos

Data type: multimedia

Explanation note: Figure S5. A male individual of Freyeria trochylus resting on grass. Rodos, 19 Nov 2019; Figure S6. The larval hostplant of F. trochylus, Andrachne telephioides, in its natural habitat. Rodos, 24 Sep 2019; Figure S7. A male individual of Z. karsandra at rest. Rodos, 19 Nov 2019; Figure S8. A worn male individual of Z. karsandra in the field. Rodos, 3 Dec 2019; Figure S9. A male individual of $Z$. karsandra resting on a fresh leaf of Ricinus communis. Rodos, 9 Nov 2019; Figure S10. The pupa of Z. karsandra next to its old larval skin on a dry leaf of its hostplant, Polygonum equisetiforme; Figure S11-S15. The natural habitats of Z. karsandra populations in 5 different localities on Rodos, where the presence of its native larval hostplant, P. equisetiforme, was confirmed.

Copyright notice: This dataset is made available under the Open Database License (http://opendatacommons.org/licenses/odbl/1.0/). The Open Database License (ODbL) is a license agreement intended to allow users to freely share, modify, and use this Dataset while maintaining this same freedom for others, provided that the original source and author(s) are credited.

Link: https://doi.org/10.3897/nl.43.48535.suppl4 